\title{
Antifungal, anti-inflammatory and cytotoxicity activities of three varieties of labisia pumila benth: from microwave obtained extracts
}

\author{
Ehsan Karimi ${ }^{1 *}$, Hawa ZE Jaafar ${ }^{1 *}$ and Syahida Ahmad ${ }^{2}$
}

\begin{abstract}
Background: Labisia pumila, locally known as Kacip Fatimah, is a forest-floor plant that has tremendous potential in the herbal industry. It is one of the five herbal plants identified by the government as one of the national key economic areas to be developed for commercial purposes. There are three varieties of L. pumila namely, L. pumila var. pumila, L. pumila var. alata and L. pumila var. lanceolata and each has its own use.
\end{abstract}

Methods: The leaves and roots of the three varieties of $L$. pumila Benth. were extracted using microwave assisted extraction (MAE). Antifungal activity of all plant extracts were characterized against Fusarium sp., Candida sp. and Mucor using the agar diffusion disc. Anti-inflammatory assays were performed using NO production by macrophage RAW 264.7 cell lines induced by LPS/IFN-g and cytotoxic activity was determined using several cancer cell lines and one normal cell line.

Results: The overall result demonstrated that leaf and root extracts of all three varieties of L. pumila exhibited moderate to appreciable antifungal activity against Fusarium sp., Candida sp. and Mucor compared to streptomycin used as positive control. Leaf and root extracts of all varieties significantly decreased NO release. However, the root extracts showed higher activity compared to the leaf extracts. Cytotoxic activity against MCF-7, MDA-MB-231 and Chang cell lines were observed with all extracts.

Conclusions: These findings suggest the potential use of L. pumila Benth. as a natural medicine and indicated the possible application of this medicinal plant such anti inflammatory activity and cytotoxic agents.

\section{Background}

Currently, there is growing interest in the application of plants as a medicinal agent since synthetic drugs have shown several side effects on the human body. Experimental investigations demonstrated that many naturally occurring agents in plant extracts have shown antioxidant, antimicrobial and anticancer potential in a variety of bioassay systems and animal models, having relevance to human disease [1]. Medicinal plants are known to have weak or strong therapeutic abilities and contribute in reducing risk of diseases of various etiologies such as inflammatory and cancer. This is attributed to the large amounts of phytoconstituents such as flavonoids, phenolics and saponins [2] found in medicinal plants. These

\footnotetext{
*Correspondence: Ehsan_b_karimi@yahoo.com; hawazej@agri.upm.edu.my ${ }^{1}$ Department of Crop Science, Faculty of Agriculture, University Putra Malaysia, Serdang, Selangor 43400 UPM, Malaysia

Full list of author information is available at the end of the article
}

bioactive compounds have received considerable attention due to their therapeutic potential for antimicrobial, anti-inflammatory, anticancer and antioxidant activities [3]. Burda and Oleszek [4] had demonstrated high antiradical activity of some flavonoids like rutin, kaempferol, morin and fustin as strong scavengers with radical scavenging activity of more than 90\%. Faried et al. [5] indicated that gallic acid isolated from Phaleria macrocarpa induced cancer cell death in various cancer cells such as breast cancer (MCF-7), gastric cancer (MKN-28) and colon cancer (HT-29, colon 201 and colon 26). Labisia pumila Benth. (Myrsinaceae) popularly known as Kacip Fatimah, is a herbaceous plant with creeping stems used by Malay women to induce and facilitate childbirth as well as a post-partum medicine. Recently, it was found that the bioactive compounds of $L$. pumila consisted of resorcinols, flavonoids and phenolic acids. These compounds have been identified as natural bioactive compounds with 
Table 1 Inhibition zones of leaf and root extracts of three varieties of Labisia pumila against pathogenic fungi at a concentration of $450 \mu \mathrm{g} /$ well

\begin{tabular}{lccc}
\hline *Sample & Fusarium sp. & $\begin{array}{c}\text { Inhibition Zone } \\
\text { (diameter in cm) }\end{array}$ & \\
\hline Pumila Leaf & $0.65^{\mathrm{c}}$ & $0.82^{\mathrm{b}}$ & $0.70^{\mathrm{c}}$ \\
Alata Leaf & $0.71^{\mathrm{b}}$ & $0.75^{\mathrm{c}}$ & $0.81^{\mathrm{b}}$ \\
Lanceolata Leaf & $0.45^{\mathrm{g}}$ & $0.67^{\mathrm{d}}$ & $0.57^{\mathrm{d}}$ \\
Pumila Root & $0.60^{\mathrm{d}}$ & $0.55^{\mathrm{f}}$ & $0.47^{\mathrm{e}}$ \\
Alata Root & $0.57^{\mathrm{e}}$ & $0.62^{\mathrm{e}}$ & $0.45^{\mathrm{f}}$ \\
Lanceolata Root & $0.49 \mathrm{f}$ & $0.51^{\mathrm{g}}$ & $0.33^{\mathrm{g}}$ \\
Streptomycin & $1.28^{\mathrm{a}}$ & $1.24^{\mathrm{a}}$ & $1.18^{\mathrm{a}}$ \\
\hline
\end{tabular}

Means with different superscripts within column are significantly different $(P<0.05)$

* Sample - methanolic extracts and standard antibiotic agent.

high biological activity [6]. Stone [7] had categorized three varieties of this herb in Malaysia namely $L$. pumila (Blume) var. alata, L. pumila (Blume) var. pumila and L. pumila var. lanceolata. Each of these varieties has different applications. Uses of this herb include treatment for dysentery, dysmenorrheal, flatulence, and gonorrhea [8]. The results of our previous experiments revealed that all three varieties of L. pumila Benth. consisted of bioactive compounds including phenolics, flavonoids and saponins which might be responsible for the enhanced antioxidant activity observed in this plant [9]. This present study was carried out to evaluate antifungal, anti-inflammatory and cytotoxic activity of leaf and root extracts derived by microwave extraction from the three varieties of Labisia pumila Benth.

\section{Methods}

Plant materials

Seedlings of the three Labisia pumila varieties were collected from places of origin at Hulu Langat (Selangor), Sungkai (Perak) and Kota Tinggi (Johore), respectively, and raised under glasshouse conditions for 18 months before use in the study. Voucher specimens were identified by the Herbarium unit, Institute of Bioscience, University Putra Malaysia (alata (Stone 6030 (KLU)), pumila ((Stone 7233 (KLU)), and lanceolata ((Stone 8385 (KLU)). Healthy and uniform seedlings in terms of leaf numbers were selected from the three varieties. The leaves and roots of selected seedlings were cleaned, separated, freeze dried and stored until further analysis.

\section{Microwave assisted extraction (MAE)}

MAE was performed using a microwave apparatus with a closed vessel system under pressure $\left(\right.$ ETHOS $^{\circledR} \mathrm{T}$
Microwave digestion/extraction system, Milestone Co., Italy) based on the method described by Xiao et al. [10] with some modifications. One gram of leaf and root samples of the three varieties of L. pumila was weighed in a clean aluminum container, and then transferred into the vessel of the Ethos E Microwave Extraction System and extracted with $30 \mathrm{ml}$ of methanol for $2 \mathrm{~min}$ $(\mathrm{p}=750 \mathrm{w})$. The extraction temperature was $60^{\circ} \mathrm{C}$. After extraction, the vessels were allowed to cool to room temperature, and the extracts were filtered and stored in a refrigerator.

\section{Antifungal activity assay}

The antifungal assay was carried out by the agar well diffusion method [11] with slight modifications. Briefly, a suspension of the tested fungi was prepared $\left(10^{5} \mathrm{spore} / \mathrm{mL}\right)$ and dispensed $(100 \mu \mathrm{L})$ uniformly on the surface of the agar plate. Small wells were cut in the agar plate using a cork borer $(6 \mathrm{~mm})$. A fixed volume of the different extracts or amphotericin B (PAA Lab., Germany) as positive control (at $450 \mu \mathrm{g} /$ well), were loaded into the wells. The plates were incubated at $29^{\circ} \mathrm{C}$ for $72 \mathrm{~h}$. The diameter of the inhibition zone around each well was then recorded in four different directions.

\section{Anti-inflammatory assay}

The murine monocytic macrophage cell line RAW 264.7 was cultured in Dulbecco's Modified Eagle Media (DMEM) (2mM L-glutamine, $45 \mathrm{~g} / \mathrm{L}$ glucose, $1 \mathrm{mM}$ sodium pyruvate, $50 \mathrm{U} / \mathrm{ml}$ penicillin; $50 \mu \mathrm{g} / \mathrm{ml}$ streptomycin) with $10 \%$ foetal bovine serum (FBS). The cells were cultured at $37^{\circ} \mathrm{C}$ with $5 \% \mathrm{CO}_{2}$ and were split twice a week. Approximately $1 \times 10^{6}$ cells/ml of RAW 264.7 cells were seeded in 96-well tissue culture plates and incubated for $24 \mathrm{~h}$ at $37^{\circ} \mathrm{C}$ with $5 \% \mathrm{CO}_{2}$. The cells were then incubated in prepared DMEM medium containing $100 \mu \mathrm{l}$ of test extract in DMSO and serially diluted, to give a final concentration of $100 \mu \mathrm{g} / \mathrm{ml}$ in $0.1 \%$ DMSO. Cells were then stimulated with $200 \mu / \mathrm{ml}$ of IFN- $\gamma$ and $10 \mu \mathrm{g} / \mathrm{ml}$ LPS for $17 \mathrm{~h}$. The presence of nitrite in the cell culture media was determined using Griess reagent and absorbance was read at $550 \mathrm{~nm}$ using the microplate reader (Spectra Max Plus 384, Molecular Devices Inc., USA). Nitrite concentration in the supernatants was determined by comparison with a sodium nitrite standard curve. The cell viability was detected by MTT cytotoxicity assay. L-NAME was used as iNOS inhibitor (control) at a concentration $250 \mu \mathrm{M}$ [12].

\section{Anti cancer activity assay}

Human cancer cell lines (MCF-7; MDA-MB-231) and Human hepatocytes (Chang liver cells) cell lines 

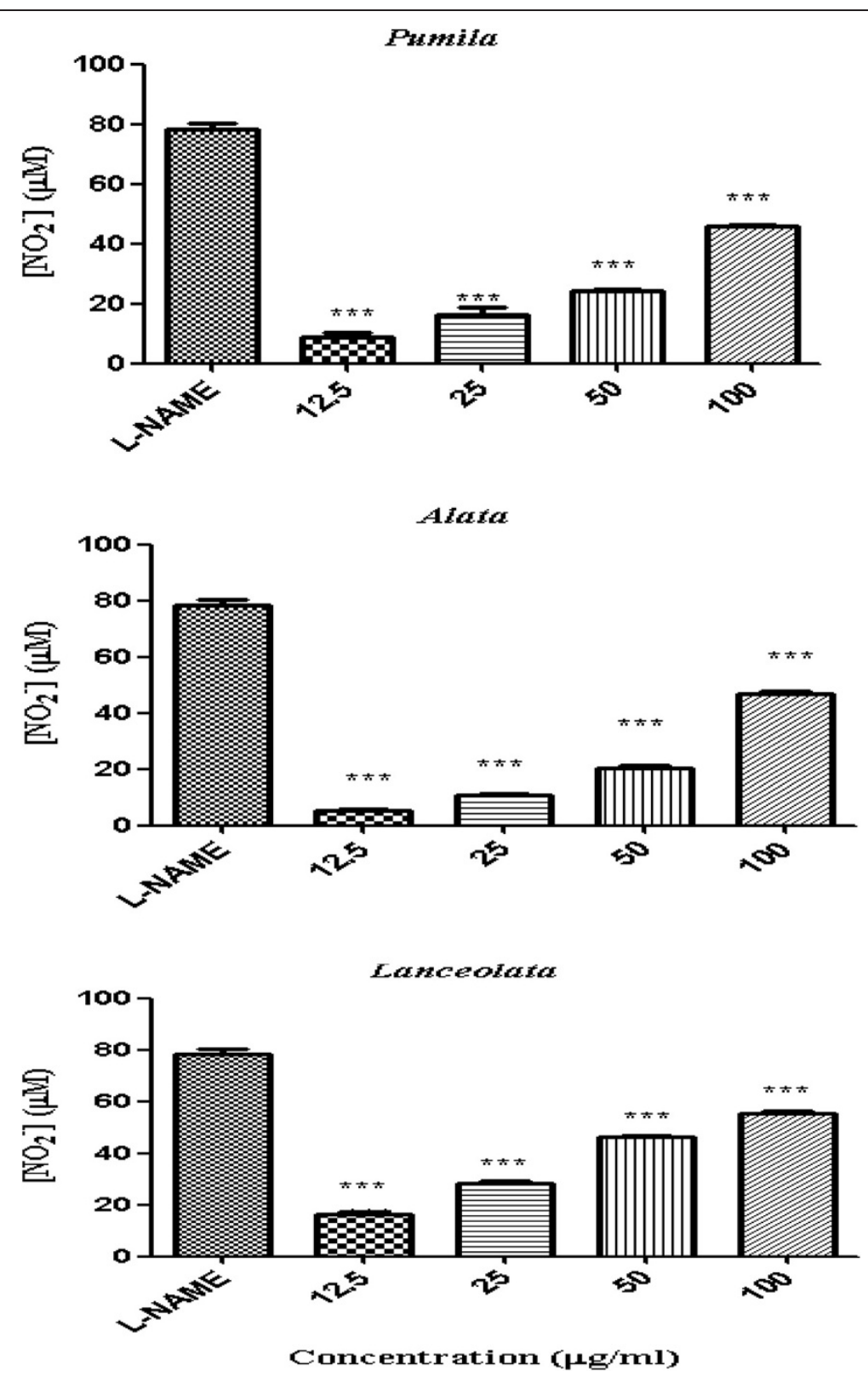

Figure 1 Percentage NO inhibition with L. pumila var. pumila, alata and lanceolata leaf extracts [All values represent mean \pm standard deviation of three different experiments; ${ }^{* *} p<0.001,{ }^{* *} p<0.01$ and ${ }^{*} p<0.05$ indicate significant difference compared to the control (L-NAME)].

obtained from the American Type Culture Collection (ATCC) were used in this study. Cells were grown at $37^{\circ} \mathrm{C}$ in humidified $5 \% \mathrm{CO}_{2}$ and $95 \%$ air atmosphere in Dulbecco's Modified Eagle Media (DMEM) (2mM Lglutamine, $45 \mathrm{~g} / \mathrm{l}$ glucose, $1 \mathrm{mM}$ sodium pyruvate, $2 \mathrm{~g} / \mathrm{l}$ sodium bicarbonate and $10 \%$ fetal bovine serum). Monolayers of cells $\left(5 \times 10^{3} / 100 \mu \mathrm{l}\right)$ were grown in 96 well microlitre plates and exposed to two fold serial dilutions of the extracts from $200 \mu \mathrm{g}$ to $3.1 \mu \mathrm{g} / 100 \mu \mathrm{l}$. After 3 days incubation at $37^{\circ} \mathrm{C}$, the cytotoxicity of extracts was determined using the MTT assay according to Ahmad et al. [12]. Tamoxifen, an anticancer drug, was used as the positive control in the present study.

\section{Statistical analysis}

Data were analyzed using the analysis of variance procedure in the Statistical Analysis System (SAS) Version 9 (SAS Institute, Cary, NC). Significant differences between means from triplicate analyses $(p<0.05)$ were 

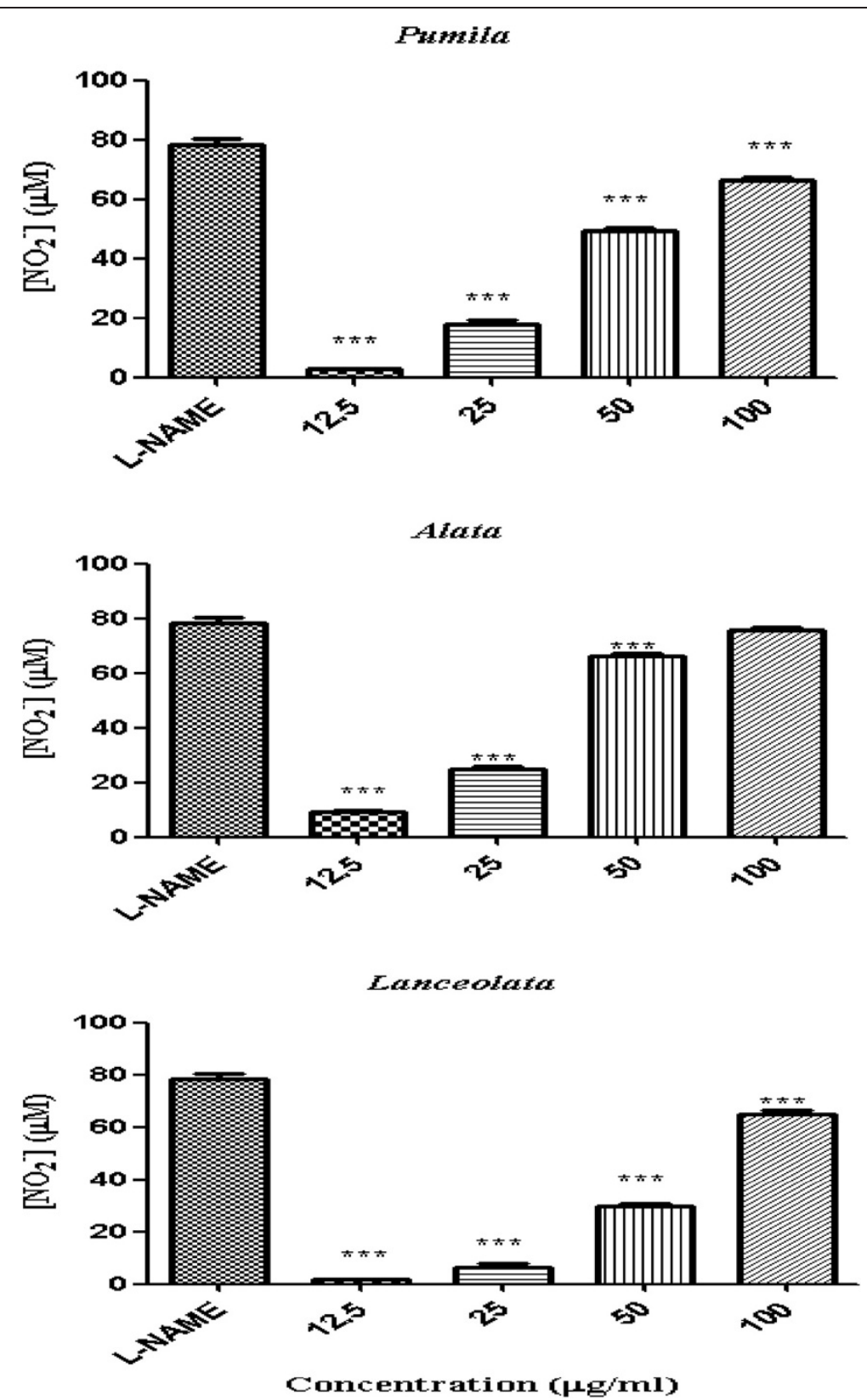

Figure 2 Percentage NO inhibition with L. pumila var. pumila, alata and lanceolata root extracts [All values represent mean \pm standard deviation. ${ }^{* *} p<0.001,{ }^{* *} p<0.01$ and ${ }^{*} p<0.05$ indicate significant difference compared to the control (L-NAME)].

determined by Duncan's Multiple Range Test. GraphPad Prism 5 software (GraphPad Software Inc., San Diego, CA) was also used in data analyses.

\section{Results and discussion}

Antifungal activity of the three varieties of Labisia pumila Benth

The results of antifungal activity of leaf and root extracts from the three varieties of Labisia pumila Benth against three fungi species are summarized in the
Table 1. In general, most of the extracts assayed exhibited weak to moderate inhibitory activity against all fungi tested. The leaves compare to roots exhibited higher activity towards the tested fungi at a concentration of $450 \mu \mathrm{g} /$ well in all three varieties. The highest inhibitory activity was observed in the leaf extract of variety pumila against Candida sp. (inhibition zone $=0.82$ $\mathrm{cm}$ ) and leaf extract of variety alata against Mucor sp. (inhibition zone $=0.70 \mathrm{~cm}$ ). The lowest inhibitory activity was obtained with the root extract of variety lanceolata 
Table 2 Effect of leaf and root extracts of three varieties of $L$. pumila Benth. on NO production and cell viability of RAW 264.7 cells

\begin{tabular}{|c|c|c|c|}
\hline $\begin{array}{l}\text { Sample } \\
\text { Extract }\end{array}$ & $\begin{array}{l}\text { Level of } \\
\text { Activity }\end{array}$ & $\begin{array}{c}\text { NO inhibition } \\
(\%)^{\mathrm{a}}\end{array}$ & $\begin{array}{c}\text { Cell viability } \\
(\%)^{a}\end{array}$ \\
\hline Pumila Leaf & weak & $45.66 \pm 1.29$ & $93.64 \pm 11.59$ \\
\hline Alata Leaf & weak & $46.64 \pm 2.10$ & $72.75 \pm 17.06$ \\
\hline Lanceolata Leaf & moderate & $55.17 \pm 1.96$ & $98.12 \pm 3.71$ \\
\hline Pumila Root & moderate & $66.45 \pm 1.84$ & $44.57 \pm 6.06$ \\
\hline Alata Root & strong & $75.68 \pm 1.70$ & $71.32 \pm 4.26$ \\
\hline Lanceolata Root & moderate & $64.81 \pm 2.22$ & $60.26 \pm 4.56$ \\
\hline $\begin{array}{l}\text { L-NAME } \\
\text { (Control) }\end{array}$ & strong & $78.43 \pm 0.97$ & $97.67 \pm 4.40$ \\
\hline
\end{tabular}

The data represent means \pm standard deviation of triplicate cultures of three independent experiments.

${ }^{\text {a }}$ Values expressed at concentration $100 \mu \mathrm{g} / \mathrm{ml}$.

against Mucor sp. (inhibition zone $=0.33 \mathrm{~cm}$ ). Antifungal activity of all the extracts is attributed to presence of bioactive compounds such as flavonoids, phenolics, saponins and various volatile compounds [13]. Various extracts of medicinal plants have also been shown to have inhibitory effects against phytopathogenic fungi in vitro [14]. Vaquero et al. [15] revealed that different concentrations of gallic acid, caffeic acid, rutin and quercitin of wine exhibited various sensitivities against pathogenic fungi.

\section{Anti-inflammatory activity of the three varieties of Labisia pumila Benth}

Nitric oxide (NO) is an important radical molecule that is produced by a family of enzymes known as nitric oxide synthase (NOS) and participates in the physiology and pathophysiology of many systems. Producing large amount of $\mathrm{NO}$ is associated with numerous pathological conditions. NO released from cells can be detected and quantified photometrically as its stable product, nitrite in the cell culture supernatant [16]. Anti-inflammatory activity of leaves and roots of the three varieties of L. pumila was evaluated based on the colorimetric nitric oxide assay. In this study, all extracts were examined for ability to inhibit NO release in RAW 264.7 cells stimulated with bacterial lipopolysaccharides (LPS) and interferon-gamma (IFN- $\gamma)$. All extracts were assayed at the two-fold dilution range $(12.5-100 \mu \mathrm{g} / \mathrm{ml})$ dissolved in $0.2 \%$ DMSO and compared with N-Nitro-L-Arginine Methyl Ester (L-NAME). The viability of RAW 264.7 cells after treatment was assessed by the MTT (3-4,5dimethylthiazol-2-yl)-2,5-diphenyl tetrazolium bromide) method. The activity profiles of the extracts in terms of percentage of $\mathrm{NO}$ inhibition were categorized according to Kim et al. [17]. Inhibition of NO production in LPS/ IFN- $\gamma$ stimulated RAW 264.7 cell lines were classified into four ranks which are: strongly active (70\% and above); moderately active (50-69\%); weakly active (30-49\%); and very weakly active (29\% or less). Figures 1 and 2 show the NO inhibition of L-NAME, leaf and root extracts of the three varieties of $L$. pumila (var. pumila, alata and lanceolata). L-NAME inhibited NO production by $78.43 \%$. The NO inhibition values of leaf extract of $L$. pumila var. pumila, alata and lanceolata were 45.66, 46.64 and 55.17\%, respectively, at a concentration of $100 \mu \mathrm{g} / \mathrm{ml}$, while the root extract of var. pumila, alata and lanceolata resulted in $66.45,75.68$ and $64.81 \%$, inhibition, respectively (Table 2). The results show that all the extracts have weak to moderate activity compare to control (Table 2). MTT assay was also performed to test the cell viability of RAW 264.7 cell lines. This step is crucial to prove that the inhibition of NO production was not false due to cell death. The cell viability with L-NAME, leaf and root extracts are shown in Figures 3 and 4 . All the extracts showed moderate activity and the percentage of cell viability was affected (Table 1). At the highest concentration used $(100 \mu \mathrm{g} / \mathrm{ml})$ percentage cell viability for each leaf and root extract of $L$. pumila was more than $65 \%$. The results suggest that leaf and root extracts of L. pumila appeared to be potent iNOS inhibitors contributing to anti-inflammatory effects and at the same time were non-toxic to Raw 264.7 cells. The potential of L. pumila Benth as an anti-inflammatory agent is attributed to the presence of phytochemicals such as flavonoids and phenolics as well as saponins. Karimi et al. [9] showed that kaempferol, naringin and myricetin were the main flavonoid compounds present in all three varieties with values of $222.8,79.4,31.1 \mu \mathrm{g} / \mathrm{g}$ dry sample in the leaves of var pumila, 187.2, 140, 88.4 $\mu \mathrm{g} / \mathrm{g}$ dry sample of var alata, and $164.6,86.7,27.9 \mu \mathrm{g} / \mathrm{g}$ dry sample of var lanceolata, respectively. The analyses also confirmed the presence of gallic acid and caffeic acid as the main phenolic compounds in all three varieties. It was also noted that all three varieties of L. pumila Benth had high saponin contents in their leaves and roots. The mechanism of phenolic compounds in antioxidant activity and their ability to act as free radical and NO scavengers, leading to the formation of phenoxyl radicals have been described by Sumanont et al. [18]. Oskoueian et al. [19] suggested that the inhibition of iNOS in the RAW 264.7 cell is due to the suppressive action of flavonoids. Furthermore, saponins isolated from roots of Physospermum verticillatum exerted significant inhibition of NO production in LPS induced RAW 264.7 macrophages [20]. Meanwhile, in vitro studies have demonstrated that phytochemicals are able to suppress iNOS and inhibit nitric oxide and this ability depends on the structure of compounds. Kim et al. [21] reported that iNOS, an enzyme-catalyzing NO production, was found to be over-expressed in chronic inflammatory diseases and various types of cancer. NO is an important regulatory molecule in inflammation response and cancer 

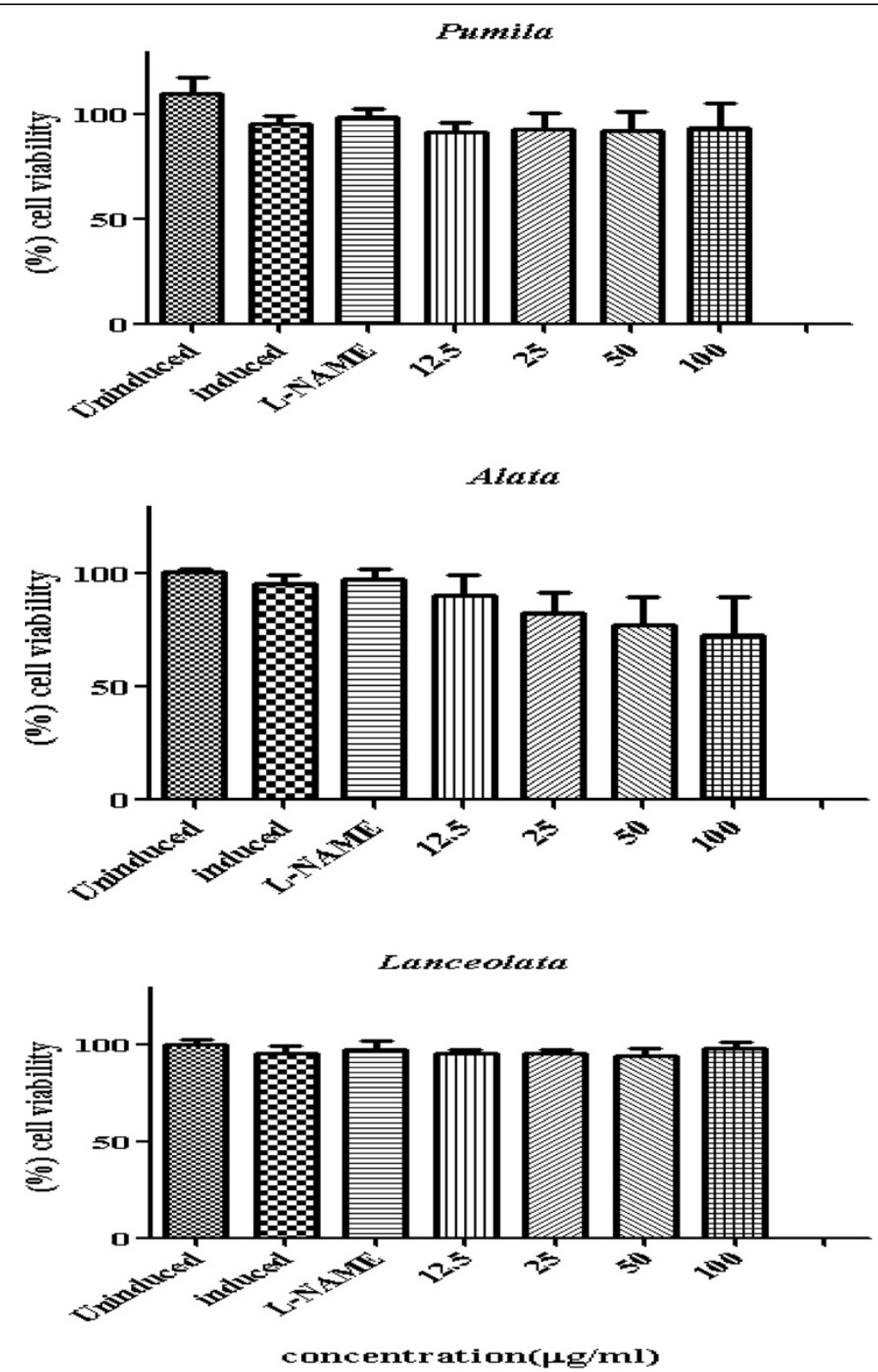

Figure 3 Effect of leaf extracts of Labisia pumila var. pumila, alata and lanceolata on viability of RAW 264.7 cells [Each bar represents the mean \pm standard deviation of three independent experiments].

development. Under the circumstances of chronic inflammation, the continuous generation of $\mathrm{NO}$ may lead to DNA damage, disruption of DNA repair, and cancer prone post-translational modification.

Anticancer activity of the three varieties of Labisia pumila Benth

Cancer is a group of diseases characterized by cells that grow out of control. In most cases, they form masses of cells, or tumors, that infiltrate, crowd out, and destroy normal tissue. Consumption of antioxidant rich fruits and vegetables in our daily diets significantly reduces the risk of many cancer diseases suggesting that antioxidants could be effective agents for the inhibition of cancer spread [22]. The results of anticancer activity of leaf and root extracts of the three varieties of Labisia pumila Benth are presented in Figures 5, 6 and 7. Increase in extract concentrations of upto $200 \mu \mathrm{g} / \mathrm{ml}$ reduced the cell viabilities significantly $(\mathrm{p}<0.001)$ in a dose-dependent manner in all three cell lines tested. The $\mathrm{IC}_{50}$ values of 

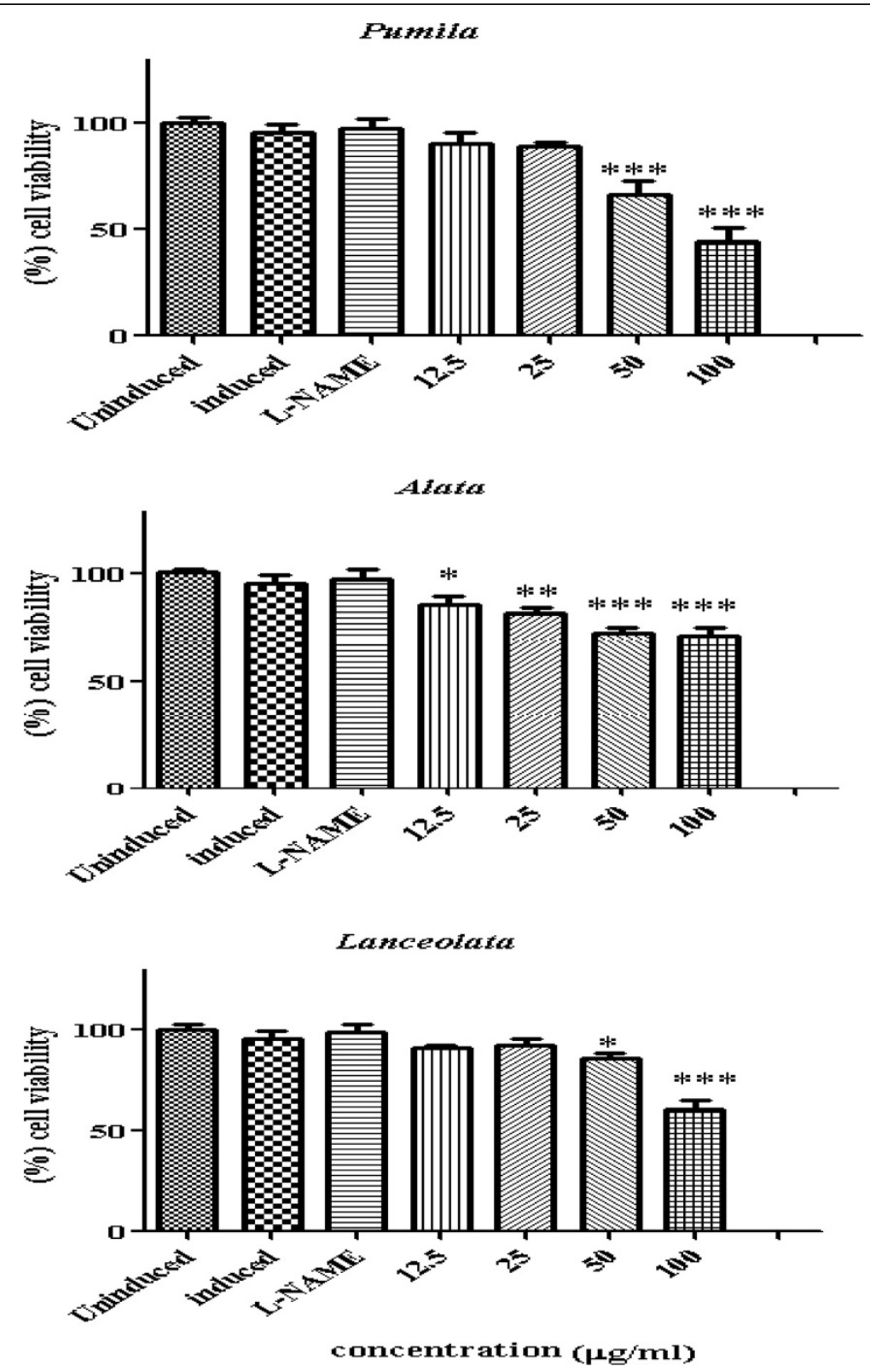

Figure 4 Effect of root extracts of Labisia pumila var. pumila, alata and lanceolata on viability of RAW 264.7 cells [Each bar represents the mean \pm standard deviation of three independent experiments].

extracts used in this study are presented in Table 3. According to the US NCI plant screening program, a crude extract is generally considered to have in vitro cytotoxic activity if the $\mathrm{IC}_{50}$ value (concentration that causes reduction in cell viability to $50 \%$ ) was less than $30 \mu \mathrm{g} / \mathrm{ml}$ [23]. Leaf extracts appeared to be more active compared root extracts for all varieties on the three cell lines tested. Labisia pumila var. pumila exhibited more cytotoxic activity compared to var. alata followed by var. lanceolata. The $\mathrm{IC}_{50}$ concentrations for leaf extracts of L. pumila var. pumila, alata and lanceolata, with the MCF7 cell line were found to be $48.2,54$ and $59.9 \mu \mathrm{g} / \mathrm{ml}$ and for MDA-MB-231 the values were 55.80, 62.26 and $66.39 \mu \mathrm{g} / \mathrm{ml}$, respectively. In terms of toxicity to the Chang liver cells, leaf and root extracts were considered as not toxic as the $\mathrm{IC}_{50}$ values were greater than $200 \mu \mathrm{g} / \mathrm{ml}$. Tamoxifen was used as the positive control in this study (Figure 8 ). The $\mathrm{IC}_{50}$ concentrations of Tamoxifen for Chang liver cell, MCF-7 and MDA-MB-231 were 34.97, 36.54 and $35.46 \mu \mathrm{g} / \mathrm{ml}$, 


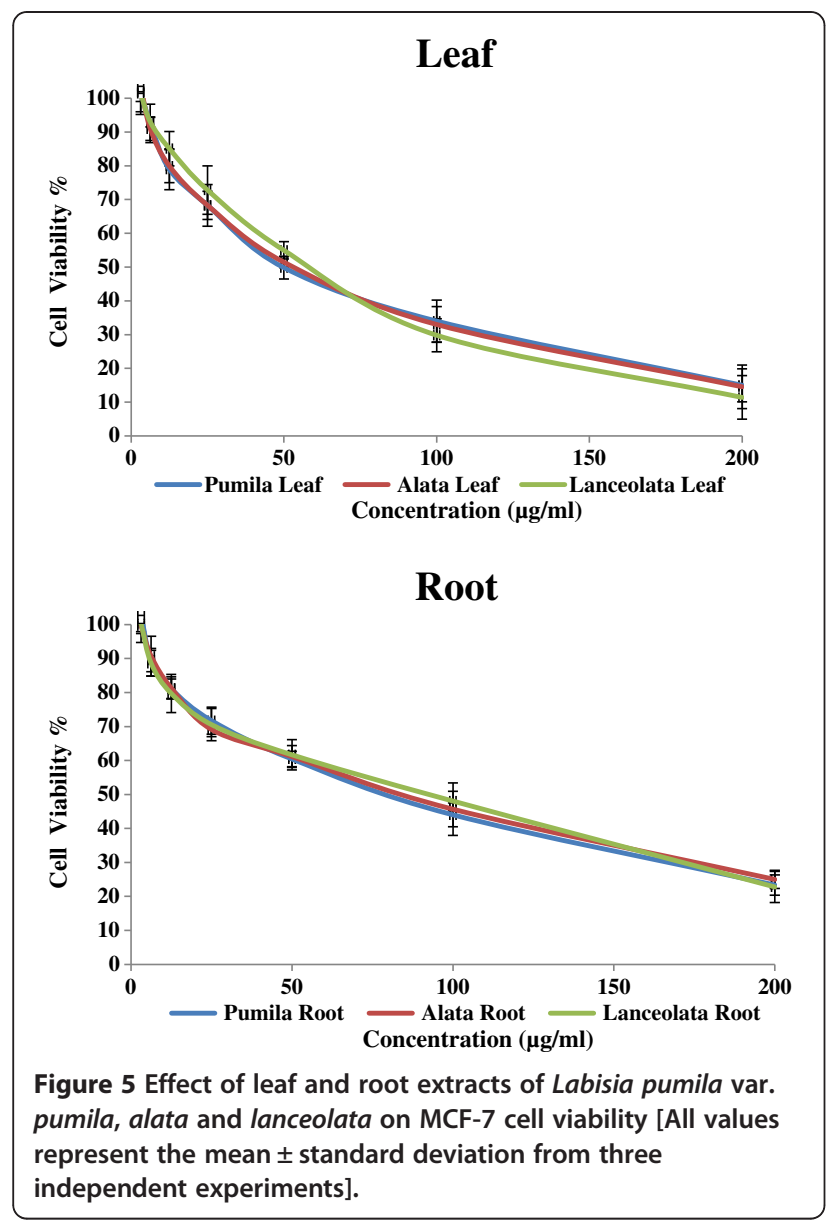

respectively (Table 3 ). The activity of Tamoxifen was found to be higher than the leaf and root extracts. Tamoxifen has been used specifically to treat breast cancer due to its antagonistic effect on estrogen receptors in breast tissue [24]. All leaf and root extracts showed anticancer activity at various concentrations. This may be attributed to the different bioactive compounds such as phenolics and flavonoids that could lead to the cytotoxic activity of this medicinal plant. Chang liver cell was also susceptible to the extracts indicating the lack of selectivity in the effect. The GC-MS analysis of methanolic extracts reported by Karimi et al. [13] demonstrated more than 25 compounds in the leaves of the three varieties of Labisia pumila Benth. Heptadecanoic acid (20.39\%), octadecanoic acid (16.24\%) and 1,3-dioxolane,2,4,5-trimethyl (18.69\%) were the main compounds in the leaf extracts of Labisia pumila var. alata, pumila and lanceolata. These compounds have been reported to have antibacterial and antifungal [25], antioxidant [26] and anticancer activities [27]. It is also known that high concentration of certain fatty acids can cause cell death via apoptosis or necrosis [28]. Oskoueian

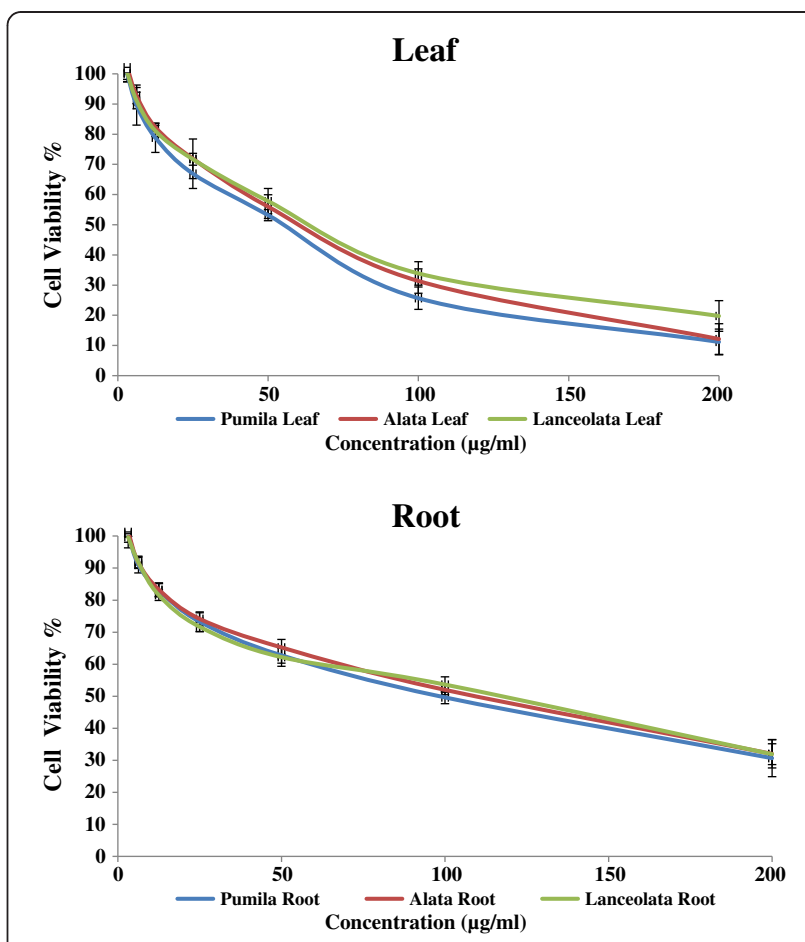

Figure 6 Effect of leaf and root extracts of Labisia pumila var. pumila, alata and lanceolata on MDA-MB 231 cell viability [All values represent the mean \pm standard deviation from three independent experiments].

et al. [19] indicated the ability of flavonoids and phenolic compounds to act as anticancer agents. Zhang et al. [29] showed that kaempferol, quercetin, anthocyanins, coumaric acid and ellagic acid isolated from strawberry inhibited the growth of human cancer cell lines for breast (MCF-7), oral (KB, CAL-27), colon (HT29, HCT-116), and prostate (LNCaP, DU-145). Similar results have also been reported in previous studies where polyphenols such as resveratrol, quercetin, catechin, and epicatechin isolated from wine extract [30] and green tea polyphenols like epigallocatechin and epicatechin [31] play an important role as anticancer agents.

\section{Conclusion}

Medicinal plants are now increasingly getting more attention than ever before. The medicinal value of these plants lies in the bioactive phytochemical constituents such as phenolics, flavonoids and saponins that result in various biological activities [32]. The results of this study showed the potential of Labisia pumila plants and in particular the leaves for use in the development of anti fungal, anti-inflammatory and anti cancer drugs using microwave extraction. These activities might be due to the presence of various phenolic and 


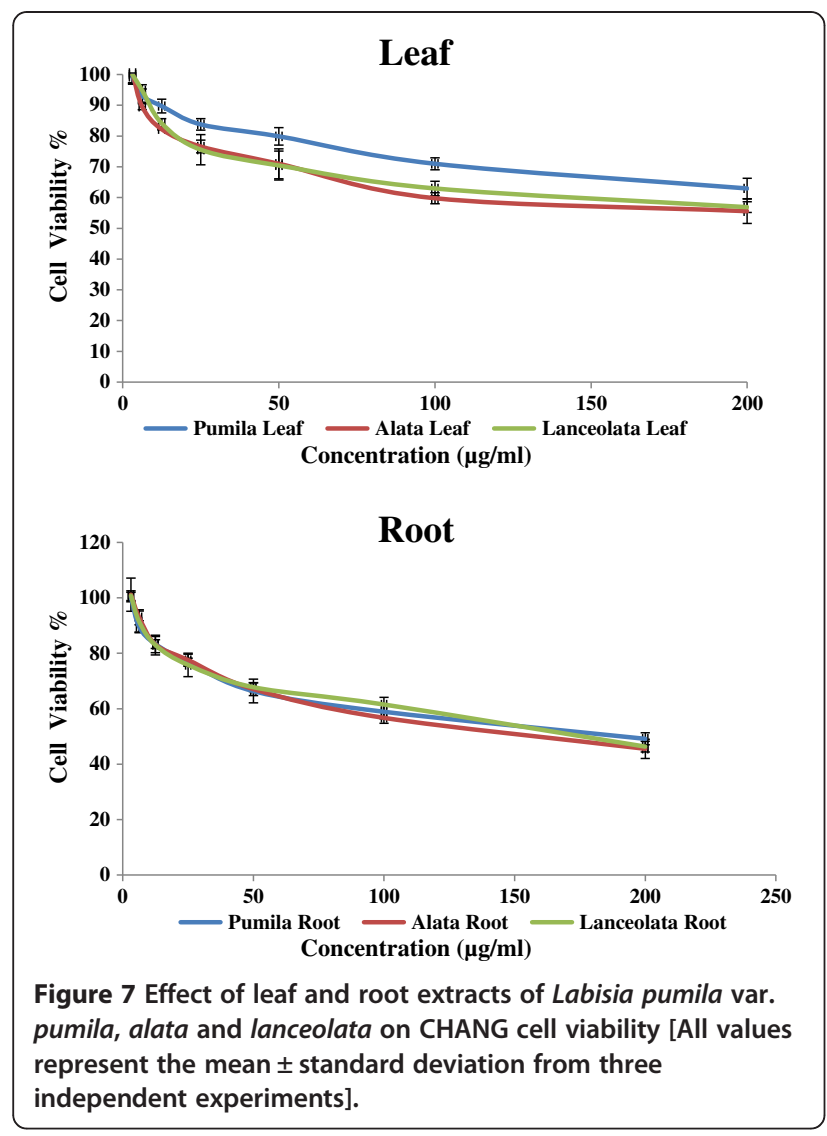

flavonoid compounds in the leaves compare to root in all three varieties of $L$. pumila Benth $[9,13]$. It should be noted that the results obtained were based on in vitro screening tests. Therefore isolation of bioactive compounds responsible for the observed activities is necessary and in vivo studies are needed for further confirmation.

Table $3 \mathrm{IC}_{50}$ values of leaf and root extracts of $L$. pumila Benth on Chang liver cells and MCF-7 and MDA-MB-231 cell lines

\begin{tabular}{|c|c|c|c|}
\hline \multirow[t]{2}{*}{ Sample } & \multicolumn{3}{|c|}{$I C_{50}$ Value $(\mu \mathrm{g} / \mathrm{ml})$} \\
\hline & Chang liver cell & MCF-7 & MDA-MB-231 \\
\hline Pumila Leaf & $>200$ & $48.19 \pm 2.59$ & $55.80 \pm 1.83$ \\
\hline Alata Leaf & $>200$ & $53.96 \pm 3.41$ & $62.26 \pm 2.92$ \\
\hline Lanceolata Leaf & $>200$ & $59.88 \pm 2.63$ & $66.39 \pm 2.74$ \\
\hline Pumila Root & $192.16 \pm 1.48$ & $81.92 \pm 2.28$ & $98.93 \pm 1.93$ \\
\hline Alata Root & $160.90 \pm 2.15$ & $86.14 \pm 2.11$ & $110.30 \pm 1.52$ \\
\hline Lanceolata Root & $176.68 \pm 0.97$ & $92.94 \pm 2.54$ & $116.87 \pm 2.41$ \\
\hline Tamoxifen (control) & $34.97 \pm 1.55$ & $36.54 \pm 0.79$ & $35.46 \pm 0.46$ \\
\hline
\end{tabular}

All analyses were mean of triplicate measurements \pm standard deviation.

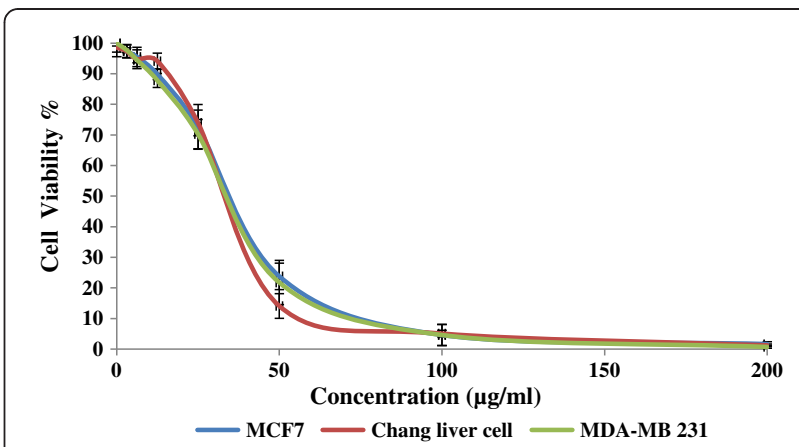

Figure 8 Effect of Tamoxifen on MCF7, Chang liver and MDAMB 231 cell viability [All values represent the mean \pm standard deviation from three independent experiments].

\section{Competing interests}

The authors declare that they have no conflicts of interest concerning this article.

\section{Authors' contributions}

EK conducted antifungal properties, cytotoxicity assay, analyze and interpretation of data, and drafted the manuscript. HZEJ was responsible for conception and design, drafted the manuscript and revised it critically for important intellectual content. SA conducted the anti-inflammatory assay, and assisted in the analysis and interpretation of data. All authors read and approved the final manuscript.

\section{Acknowledgements}

The authors would like to thank the Ministry of Higher Education Malaysia, and the Research Management Centre, Universiti Putra Malaysia (UPM) for sponsoring this work. Authors also wish to acknowledge the support given by the Faculty of Agriculture, and the Faculty of Biotechnology and Biomolecular Sciences, University Putra Malaysia in terms of laboratory facilities.

\section{Author details}

'Department of Crop Science, Faculty of Agriculture, University Putra Malaysia, Serdang, Selangor 43400 UPM, Malaysia. ${ }^{2}$ Department of Biochemistry, Faculty of Biotechnology and Biomolecular Sciences, University Putra Malaysia, Serdang, Selangor 43400 UPM, Malaysia.

Received: 10 October 2012 Accepted: 22 January 2013

Published: 24 January 2013

\section{References}

1. Aziz KA, Till KJ, Chen H, Slupsky JR, Campbell F, Cawley JC, Zuzel M: The role of autocrine FGF-2 in the distinctive bone marrow fibrosis of hairycell leukemia (HCL). Blood 2003, 102(3):1051-1056.

2. Kris-Etherton PM, Lefevre M, Beecher GR, Gross MD, Keen CL, Etherton TD: Bioactive compounds in nutrition and health research methodologies for establishing biological function: the antioxidant and anti-inflammatory effects of flavonoids on atherosclerosis. Annu Rev Nutr 2004, 24:511-538.

3. Rathee P, Chaudhary H, Rathee S, Rathee D, Kumar V, Kohli K: Mechanism of action of flavonoids as anti-inflammatory agents: a review. Inflamm Allergy Drug Targets 2009, 8(3):229-235.

4. Burda S, Oleszek W: Antioxidant and antiradical activities of flavonoids. Agricul. Food. Chem 2001, 49:2774-2779.

5. Faried A, Kurnia D, Faried L, Usman N, Miyazaki T, Kato H, Kuwano H: Anticancer effects of gallic acid isolated from Indonesian herbal medicine, Phaleria macrocarpa (Scheff.) Boerl, on human cancer cell lines. Int J Oncol 2007, 30:605-613.

6. Jaafar HZE, Haris NBM, Rahmat A: Accumulation and partitioning of total phenols in two varieties of Labisia pumila Benth. under manipulation of greenhouse irradiance. Acta. Horti 2008, 797:387-392. 
7. Stone BC: Notes on the Genus Labisia Lindl. (Myrsinaceae). Malay Nat J 1988, 42:43-51.

8. Ibrahim MH, Jaafar HZE, Asmah R, Zaharah AR: Involvement of nitrogen on flavonoids, glutathione, anthocyanin, ascorbic acid and antioxidant activities of Malaysian medicinal plant Labisia pumila Blume (Kacip Fatimah). Int J Mol Sci 2012, 13:393-408.

9. Karimi E, Jaafar H, Ahmad S: Phytochemical analysis and antimicrobial activities of methanolic extracts of leaf, stem and root from different varieties of labisa pumila benth. Molecules 2011, 16:4438-4450.

10. Xiao WH, Han L, Shi B: Microwave-assisted extraction of flavonoids from Radix Astragali. Sep Purif Technol 2008, 62:614-618.

11. Quiroga EN, Sampietro AR, Vattuone MA: Screening antifungal activities of selected medicinal plants. J Ethnopharmacol 2001, 74:89-96.

12. Ahmad R, Ali AM, Israf DA, Ismail NH, Shaari K, Lajis NH: Antioxidant, radical-scavenging, anti-inflammatory, cytotoxic and antibacterial activities of methanolic extracts of some Hedyotis species. Life Science 2005, 76:1953-1964.

13. Karimi E, Jaafar HZE: HPLC and GC-MS determination of bioactive compounds in microwave obtained extracts of three varieties of labisia pumila benth. Molecules 2011, 16:6791-6805.

14. Shalini, Srivastava R: Antifungal activity screening and HPLC analysis of crude extracts from Tectona grandis, Shilajit, Valeriana wallachi. J Env Agricult Food Chem 2009, 8:218-229.

15. Vaquero MJR, Alberto MR, Nadra MCM: Antibacterial effect of phenolic compounds from different wines. Food Control 2007, 18:93-101.

16. Dirsch VM, Stuppner H, Vollmar AM: The Griess assay: suitable for a bio guided fractionation of anti-inflammatory plant extracts? Planta Med 1998, 64:423-426.

17. Kim O, Murakami A, Nakamura Y, Ohigashi H: Screening of edible Japanese plants for nitric oxide generation inhibitory activities in RAW 264.7 cells. Cancer Lett 1998, 125:199-207.

18. Sumanont $Y$, Murakami $Y$, Tohda M, Vajragupta O, Matsumoto K, Watanabe $\mathrm{H}$ : Evaluation of the nitric oxide radical scavenging activity of manganese complexes of curcumin and its derivative. Biol Pharmaceut Bull 2004, 27(2):170-173.

19. Oskoueian E, Abdullah N, Zuhainis SW, Omar AR, Ahmad S, Kuan WB, Zolkifli NA, Hendra R, Ho YW: Antioxidant, anti-inflammatory and anticancer activities of methanolic extracts from Jatropha curcas Linn. J Med Plant Res 2011, 5(1):49-57.

20. Tundis R, Bonesi M, Deguin B, Loizzo MR, Menichini F, Conforti F, Tillequin F, Menichini F: Cytotoxic activity and inhibitory effect on nitric oxide production of triterpene saponins from the roots of Physospermum verticillatum (Waldst \& Kit) (Apiaceae). Bioorg Med Chem 2009, 17(13):4542-4547.

21. Kim Y, Woo K, Lim J, Kim S, Lee T, Jung E, Lee J, Park J, Kwon T: 8-Hydroxyquinoline inhibit iNOS expression and nitric oxide production by down-regulation LPS-induced activity of NF- $\gamma$ B and C/EBP $\beta$ in Raw 264.7 cells. Biochem Biophys Res Communs 2005, 329:591-597.

22. Fresco P, Borges F, Diniz C, Marques MP: New insights on the anticancer properties of dietary polyphenols. Med Res Rev 2006, 26:747-766.

23. Boik J: Natural compounds in cancer therapy". Minnesota USA: Oregon Medical Press; 2001.

24. Hoskins JM, Carey LA, McLeod HL: CYP2D6 and tamoxifen: DNA matters in breast cancer. Nat Rev Cancer 2009, 9(8):576-586.

25. Agoramoorthy G, Chandrasekaran M, Venkatesalu V, Hsu MJ: Antibacterial and antifungal activities of fatty acid methyl esters of the blind-your-eye mangrove from India. Braz J Microbiol 2007, 38:739-742.

26. Zhang Y, Wei D, Guo S, Zhang X, Wnag M, Chen F: Chemical components and antioxidant activity of the volatile oil from Cassia tora L. seed prepared by supercritical fluid extraction. J Food Lipids 2007, 14(4):411-423.

27. Lukevics E, Ignatovich I, Shestakova I: Synthesis, psychotropic and anticancer activity of 2,2-dimethyl-5-[5/-trialkylgermyl(silyl)-2/hetarylidene]-1,3-dioxane-4,6-diones and their analogues. Appl Organomet Chem 2003, 17:898-905

28. Andrade LN, de Lima TM, Curl R, Castrucci AM: Toxicity of fatty acids on murine and human melanoma cell lines. Toxicol In Vitro 2005, 19:553-660

29. Zhang Q, Ye M: Chemical analysis of the Chinese herbal medicine GanCao (licorice). J Chromatogr A 2008, 1216:1954-1969.

30. Kampa M, Hatzoglou A, Notas G, Damianaki A, Bakogeorgou E, Gemetzi C, Kouroumalis E, Martin PM, Castanas E: Wine antioxidant polyphenols inhibit the proliferation of human prostate cancer cell lines. Nutr Cancer 2000, 37:223-233.

31. Weisburg JH, Weissman DB, Sedaghat T, Babich H: In vitro anti-cancer of epigallocatechin gallate and tea extracts to cancerous and normal cells from the human oral cavity. Basic Clin Pharmacol Toxicol 2004, 95:191-200.

32. Akinmoladun A, Ibukun E, Afor E, Obuotor E, Farombi E: Phytochemical constituent and antioxidant activity of extract from the leaves of Ocimum gratissimum. Sci Res Essays 2007, 2:163-166.

doi:10.1186/1472-6882-13-20

Cite this article as: Karimi et al:: Antifungal, anti-inflammatory and cytotoxicity activities of three varieties of labisia pumila benth: from microwave obtained extracts. BMC Complementary and Alternative Medicine 2013 13:20.

\section{Submit your next manuscript to BioMed Central and take full advantage of:}

- Convenient online submission

- Thorough peer review

- No space constraints or color figure charges

- Immediate publication on acceptance

- Inclusion in PubMed, CAS, Scopus and Google Scholar

- Research which is freely available for redistribution 